\title{
Aging and Thyroid
}

\author{
Shozo TSUJI and H. OGURA \\ 2nd Division of Internal Medicine, Kobe University, School of Medicine, Kobe, Japan
}

The problem was discussed from two viewpoints, the one from the pathological changes of the thyroid accompanying the aging, and the other from the role of the thyroid expected to be playing in the process of aging. A) Change of the thyroid function in aged people. (1) Morphological findings of thyroid in 153 autopsy materials disclosed increasing formation of lymphfollicles and connective tissues with the advance of age, but simultaneous TA-Test, precipitation test, and TRG-Test showed no positive incidence in 20 cases over 65 years of age. As summary although a general aging tendency of thyroid is suspected from weight decrease etc., pictures corresponding to euthyroidism are still abundantly found, indicating the sufficient response of thyroid to the hormonal need of peripheral tissue in old age. (2) Changes of thyroid hormone with the advance of age. A gradual decrease of Tetrasorb-125 and a decrease of TSH activity of blood (Bakke-Ogura's method), which starts relatively early, were shown in old people but PBI were not changed. Studies on the distribution of thyroid hormone in the plasma disclosed significant increase of total TBG capacity and decrease of TBPA. Increase of TBG in the old people was postulated as to be playing a role of buffer effect in the process of turn over of thyroxine to free active form. Analysis of free Thyroxine disclosed increase of free $\mathrm{T}_{4} \%$ corresponding to the decrease of TBPA but no difference in free $\mathrm{T}_{4}$ iodine and free $\mathrm{T}_{4}$ concentration between old and young people. As summary decrease of TBPA was evaluated as to be responsible for the increase of free $\mathrm{T}_{4} \%$ in old people. (3) Metabolism of thyroxine in the peripheral tissue. Investigation of turnover of $\mathrm{I}^{131}$-Thyroxine was carried out under medication of potassium perchloride $600 \mathrm{mg} /$ day disclosed prolonged half-life an decrease of turnover rate in old people. (4) TSH-Test on old people, disclosed sufficient response of thyroid to TSH. Relation of free $\mathrm{T}_{4} \%$ to TBG, endogenous TBG and TBPA were studied in young and old people after administration of thyroid powder. A significantly lower increase of $1.8 \%$ was observed in old people in comparisson to $16.6 \%$ of young people. This finding seems to point upon the possible buffer effect of increased TBG of old people. (5) Arteriosclerosis and thyroid. Determination of secretary capacity of TSH was carried out in normal old people and patients suffering from senile dementia, caued by cerebral arteriosclerosis both under excessive antithyroid medication. TSH secretion of senile dementia patients was clearly lower than normal old people. Furthermore, dogs with bilateral ligation of internal carotid arteries, showing in average 18\% decrease of circulating cerebral blood flow was treated with hemithyroidectomy. A much lower TSH increase 
in blood was shown compared with the normal response of untreated dogs. The authors postulated a possible impairment of feed back mechanism in old age basing upon the decrease of cerebral circulating blood volume caused by cerebral arteriosclerosis. B) (1) Age estimation using standard point system consisting of various physiological finding such as vital capacity, retractivity of skin, auditory activity and skeletal X-ray findings was carried out on 33 cases of hypothyroidism and on 882 cases of euthyroidism. In average 10 years of advanced age was found in hypothyroid patients in comparison to normal subjects of corresponding age. Consequently promotion of pathological aging was suspected in hypothyroid patients. (2) Prognosis of hypothyroid patients was followed up from the veiw point of life-expectancy. Statistical studies in 83 cases of thyroidectomized patients on account of Hashimoto's disease revealed 14 deaths, which did not exceed the expected death percent as regard to life expectancy. The conclusion was, that the thyroidectomized patients did live longer than normal subjects and hypothyroidism may be advantageous for long life.

\section{SUMMARY}

Thyroid seems to undergo gradual lowering of it's function along with the advance of age parallel with the lowering of cellular metabolism, but under reservation of potent capacity to react upon TSH for long time. Significant increase of TBG capacity in old age seems to be playing a role as a buffer system against over normal increase of thyroid hormone in blood. Furthermore a distinct impairment of feedback mechanism between thyroid and hypothalamo-pituitary system was demonstrated in old people. As a cause of this impairment possible decrease of cerebral circulating blood volume, basing upon cerebral arteriosclerosis, was postulated. Hypothyroidism seems to promote the pathological aging and this corresponds to the clinical impression of hypothyroid patients showing frequently far more advanced age than real age. But from the standpoint of life expectancy mild hypothyroidism seems to be advantageous for long life. The last postulation is supported by the relatively mild lowering of thyroid function, corresponding to the lowered metabolism of the tissue, in old people.

(See pp. 723 732) 


\section{Thyroid Function in Childhood}

\section{Hironori NAKAJIMA}

Department of Pediatrics, Chiba University School of Medicine, Chiba City, Japan

Until the 5 th day after birth in the neonatal period, ${ }^{131} \mathrm{I}$-thyroidal uptake, serum $\mathrm{T}_{4},{ }^{131} \mathrm{I}-\mathrm{T}_{3}$ resin uptake, and free $\mathrm{T}_{4}$ index are high, definitely indicating the state of physiological hyperactivity of the thyroid.

In the course of development from the infantile to adult period, none of these 4 parameters showed significant variations. However, plasma inorganic iodine is lower and renal iodide clearance and thyroidal iodide clearance is higher as the age of the subject is younger, indicating more active iodine metabolism in younger age.

Since iodine uptake is abundant in each age group, no possibility of deficiency is expected. With regard to $\mathrm{T}_{4}$ metabolism, both $\mathrm{T}_{4}$ turnover rate and $\mathrm{T}_{4}$ degradation rate was higher in younger age. TBG and TBPA also varied according to age. Male to female difference was seen after adolescence probably due to the influence of sex hormone. Based on these results, the physiological goiter frequently seen in adolescent females is probably not due to the increase in the requirement of thyroid hormone, iodine deficiency, and increase of renal iodide clearance but is apparently under the influence of estrogens.

(See pp. 732 733) 


\section{シンポジゥム I 加令と内分泌}

\section{4. 加令と甲状腺}

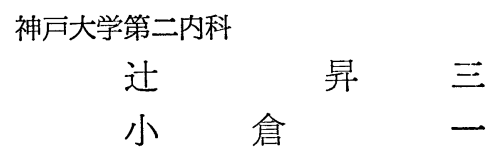

甲状腺は身体の諸機能を調節している重要な内分泌腺で，てれと加令との相関をみるてとは，きわめて大 切な課題と考える. 吾々の教室では，乙の問題に対して次の 3 つのシンポジウムを担当してきた．1つは第 11 回日本内分必学会西部地方会における，“動脈硬化と内分泌”であり，1つは，第17回日本医学会総会で “老化の内分泌学的背景”であり 2 ，今 1 つは，第19回の日本体質学会にわける “長寿と内分泌”というテ 一マである ${ }^{3)}$. 今回はてれらの報告の内，加令と甲状腺とついての成績をまとめ，三，三の新しい知見を追 加して報告する.

まづ本題に対し次の 2 つの観点から論じたい. 1 つは加令にともなう甲状腺の変化であり, 今 1 つは, 加 令現象に及ぼす甲状腺の役割である。

\section{A. 加令にともなう甲状腺の変化}

\section{1) 形態学的変化}

当大学病理学教室で剖検した153例の甲状腺重量の統計から加令的変化は Tabel. 1, Fig. 1 の如く30才

Table 1. Changes of thyroid weight along with aging

\begin{tabular}{c|r|c|c|c}
\hline Age & cases & 占 & cases & 우 \\
\hline \hline $21 \sim 25$ & 3 & $18.4 \pm 2.9$ & 3 & $19.0 \pm 5.6$ \\
$26 \sim 30$ & 8 & $19.0 \pm 5.6$ & 7 & $18.7 \pm 5.7$ \\
$31 \sim 35$ & 7 & $16.6 \pm 3.8$ & 4 & $15.4 \pm 5.9$ \\
$36 \sim 40$ & 4 & $17.7 \pm 2.9$ & 3 & $16.2 \pm 4.0$ \\
$41 \sim 45$ & 5 & $18.0 \pm 4.1$ & 4 & $16.2 \pm 4.5$ \\
$46 \sim 50$ & 4 & $17.0 \pm 3.5$ & 3 & $16.6 \pm 4.0$ \\
$51 \sim 55$ & 11 & $17.8 \pm 4.5$ & 8 & $16.2 \pm 2.8$ \\
$56 \sim 60$ & 7 & $17.3 \pm 5.3$ & 5 & $16.3 \pm 3.7$ \\
$61 \sim 65$ & 12 & $15.8 \pm 3.0$ & 9 & $15.2 \pm 4.5$ \\
$66 \sim 70$ & 9 & $16.5 \pm 5.6$ & 7 & $15.4 \pm 3.8$ \\
$71 \sim 75$ & 7 & $15.2 \pm 2.7$ & 7 & $13.5 \pm 6.1$ \\
$76 \sim 80$ & 3 & $15.2 \pm 2.7$ & 4 & $14.4 \pm 3.8$ \\
$81 \sim 85$ & 3 & $15.0 \pm 7.4$ & 3 & $13.9 \pm 1.8$ \\
$86 \sim 90$ & 2 & $13.5,14.0$ & 1 & 12.8 \\
\hline & 85 & & 68 & \\
\hline
\end{tabular}

Fig. 1. Changes of weight of endocrine organs along with aging

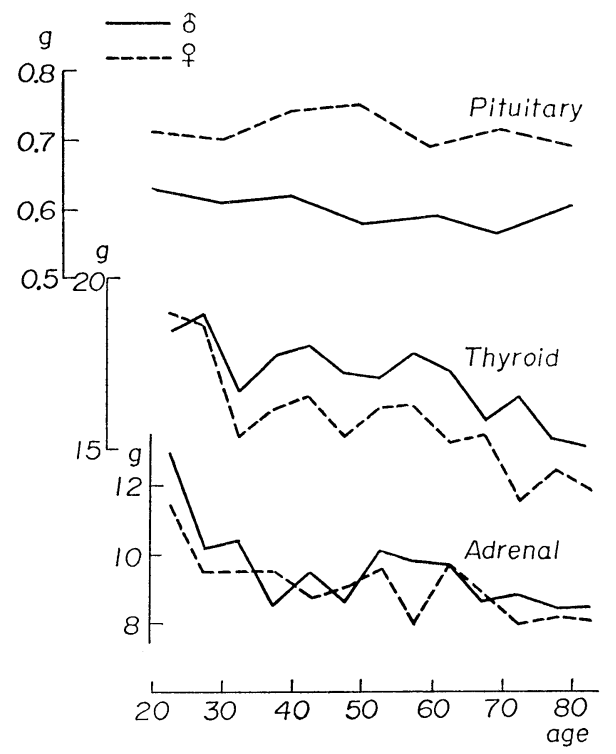


Table 2. Age changes of weight of endocrine organs along with aging

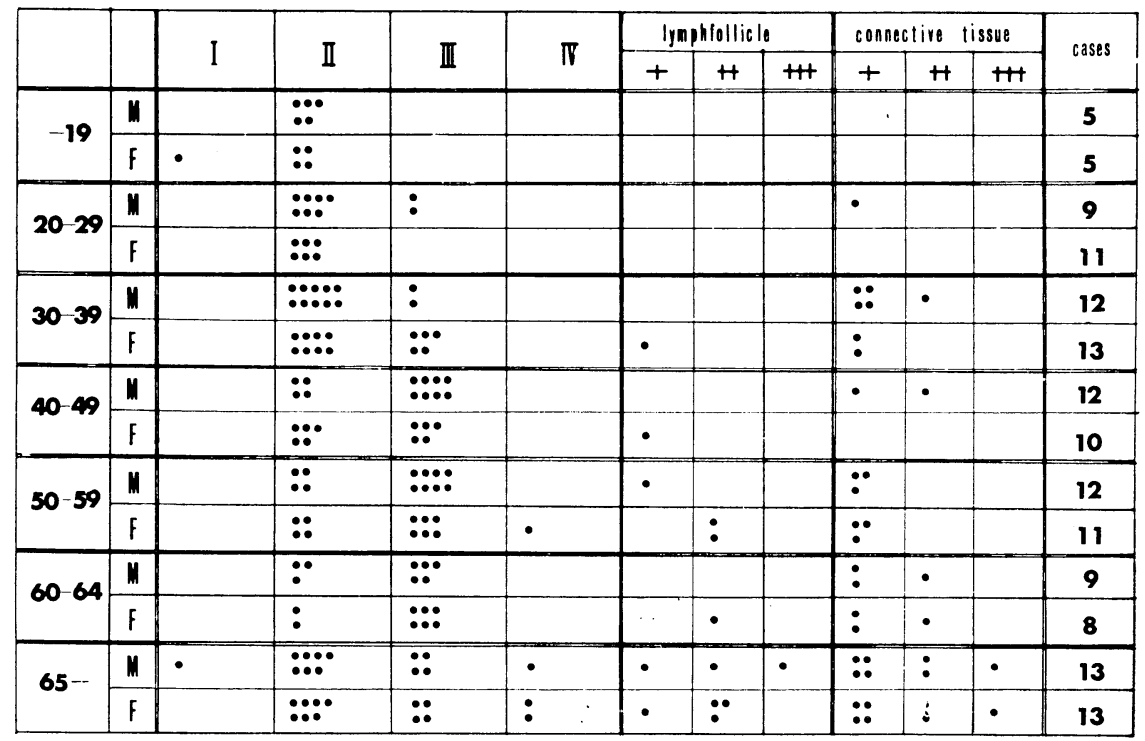

以後漸次減少してゆく結果をえた。次に組織像からみた所見をのべると，教室の入江 ${ }^{4)}$ の分類にしたがつて 甲状腺機能状態を 4 つに分類した．Ｉ型は機能六進像を，II型は正常像を，III型は機能低下を，IV型は機能 休止乃至萎縮像を示す．Table 2 は，133例の結果を示す．表の如く，加令にともない而型が多くなるが， 65才以上ではIV型も多くなり，II型を示すものもかなりみられる，又一例の機能六進を思わせる71才男子の 像もみられた。

又，中欄はリンパ濾胞形成の度合を示すが，やはり加令にともない増加の傾向がみられたが，65才以上の 20例について，TA-Test, 沈降反応，TRC などを行なつたが全て陰性であつた。右欄は，間質の増生度を 示し，加令にともない老化の傾向はみられるが，65才以上でもかなり正常像を示すものが多く，末梢組織の 甲状腺ホルモン需要に充分対処しうると推定された。

\section{2. 甲状腺ホルモン量の加令に伴う変化}

PBI 值, Tetrasorb-125, TSH 活性 (Bakke-Ogura 法)，の加令にともなう変動を実測值で示し，(Table 3, Table 4, Table 5) 乙れを図示した。 (Fig. 2, Fig. 3) PBI 值は大きな変動を示さず，Tetrasorb

Table 3. PBI in aging

\begin{tabular}{c|c|c|c|c}
\hline \hline Age & Cases & 占 & Cases & ㅇ \\
\hline \hline $10 \sim 19$ & 7 & $6.3 \pm 1.08$ & 6 & $6.2 \pm 1.02$ \\
$20 \sim 29$ & 7 & $6.3 \pm 1.31$ & 8 & $6.4 \pm 1.17$ \\
$30 \sim 39$ & 8 & $6.4 \pm 0.72$ & 5 & $6.4 \pm 0.83$ \\
$40 \sim 49$ & 5 & $6.4 \pm 1.00$ & 4 & $6.0 \pm 0.63$ \\
$50 \sim 59$ & 7 & $6.2 \pm 0.77$ & 6 & $6.1 \pm 0.89$ \\
$60 \sim 69$ & 7 & $6.3 \pm 1.86$ & 7 & $6.3 \pm 2.34$ \\
$70 \sim 79$ & 6 & $5.1 \pm 1.14$ & 6 & $5.1 \pm 0.09$ \\
$80<$ & 4 & $5.1 \pm 0.98$ & 5 & $4.9 \pm 1.40$ \\
\hline
\end{tabular}

Table 4. Tetrasorb in aging

\begin{tabular}{r|c|c|r|c}
\hline Age & Cases & Male & Cases & Female \\
\hline \hline$\sim 20$ & 7 & $9.1 \pm 1.1$ & 10 & $8.8 \pm 1.9$ \\
$21 \sim 30$ & 8 & $8.8 \pm 1.9$ & 9 & $8.7 \pm 1.5$ \\
$31 \sim 40$ & 6 & $8.1 \pm 1.9$ & 6 & $7.4 \pm 1.7$ \\
$41 \sim 50$ & 7 & $7.2 \pm 2.0$ & 9 & $7.8 \pm 1.9$ \\
$51 \sim 60$ & 7 & $7.4 \pm 1.4$ & 8 & $8.3 \pm 2.2$ \\
$61 \sim 70$ & 6 & $7.4 \pm 1.4$ & 6 & $6.6 \pm 2.4$ \\
$71 \sim 80$ & 8 & $6.0 \pm 3.0$ & 16 & $6.3 \pm 1.7$ \\
$81 \sim 90$ & 1 & 6.1 & 1 & 8.1 \\
$91 \sim 100$ & - & - & 2 & $5.5,8.6$ \\
\hline Average & 50 & $7.7 \pm 2.1$ & 67 & $7.6 \pm 2.0$ \\
\hline
\end{tabular}


は, 徐々に減少を, TSH 值は, 比較的早期より低 下傾向がみられた. Table 6 は, 平均令27才の若年 群と, 平均年令 80 才の老人群について甲状腺ホルモ ンの存在様式を示したものである．老人では有意の total TBG capacity の増加と, TBPA の減少がみ られた. この老人における TBG の増加は, 何らか の原因で甲状腺ホルモンが血中で増加した場合には, この TBG に結合して, サイロキシンの遊離型へ の移行をおくらせる Buffer 様の作用を演じるので はないかと推定した. Table 7 は, starling の平 衡透析法 ${ }^{5}$ によつて測定した free $\mathrm{T}_{4}$ 值を示す. 表 の如く老人において free $\mathrm{T}_{4} \%$ は有意に高く, 乙 れに対して free $\mathrm{T}_{4}$ iodine, free $\mathrm{T}_{4}$ concentration

Fig. 2. Average value of thyroid hormones in aging male

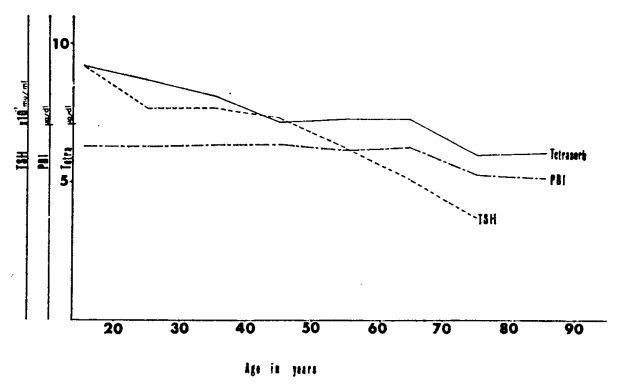

Table 5. Plasma TSH level in aging $(\mathrm{mu} / \mathrm{ml})$

\begin{tabular}{c|c|c|c|c}
\hline Age & Cases & 占 & Cases & 早 \\
\hline \hline $10 \sim 19$ & 4 & $0.091 \pm 0.033$ & 6 & $0.103 \pm 0.048$ \\
$20 \sim 29$ & 6 & $0.077 \pm 0.048$ & 7 & $0.096 \pm 0.060$ \\
$30 \sim 39$ & 4 & $0.079 \pm 0.033$ & 5 & $0.099 \pm 0.061$ \\
$40 \sim 49$ & 5 & $0.073 \pm 0.043$ & 6 & $0.093 \pm 0.064$ \\
$50 \sim 59$ & 4 & $0.064 \pm 0.027$ & 4 & $0.070 \pm 0.032$ \\
$60 \sim 69$ & 5 & $0.051 \pm 0.040$ & 5 & $0.062 \pm 0.054$ \\
$70 \sim 79$ & 3 & $0.038 \pm 0.026$ & 3 & $0.038 \pm 0.043$ \\
80 & 2 & $0.046,0.014$ & 1 & 0.037 \\
\hline
\end{tabular}

TSH-assay by Bakke-Ogura's method

Fig. 3. Average value of thyroid hormones in aging female

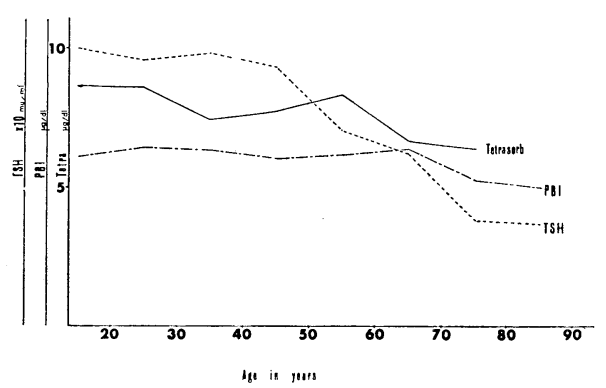

Table 6. Comparison of thyroid function in old and young age group

\begin{tabular}{l|r|r|r|r|r}
\hline & \multicolumn{1}{|c|}{ Old } & cases & Young & cases & P \\
\hline PBI $\mu \mathrm{g} / \mathrm{dl}$ & $5.4 \pm 1.2$ & 31 & $5.8 \pm 2.5$ & 32 & $\mathrm{~N} . \mathrm{S}$ \\
Triosorb \% & $39.5 \pm 3.7$ & 40 & $31.1 \pm 2.9$ & 60 & $\mathrm{~N} . \mathrm{S}$ \\
total TBG Cap. $\mu \mathrm{g} / \mathrm{dl}$ & $35.9 \pm 4.3$ & 21 & $21.5 \pm 4.3$ & 14 & $<0.01$ \\
end. TBG $\mu \mathrm{g} / \mathrm{dl}$ & $8.3 \pm 1.9$ & 6 & $7.2 \pm 0.8$ & 5 & $\mathrm{~N} . \mathrm{S}$ \\
TBPA $\mu \mathrm{g} / \mathrm{dl}$ & $96.6 \pm 9.5$ & 8 & $125.0 \pm 8.1$ & 5 & $<0.01$ \\
free $\mathrm{T}_{4}$ Index & $4.7 \pm 0.8$ & 15 & $5.5 \pm 0.6$ & 5 & $\mathrm{~N} . \mathrm{S}$ \\
\hline
\end{tabular}

Table 7. $\mathrm{F}_{-} \mathrm{T}_{4}$ in old and young aged

\begin{tabular}{l|c|c|c}
\hline & Old 21 cases & Young 14 cases & P \\
\hline \hline $\mathrm{F}_{-} \mathrm{T}_{4} \%$ & $0.041 \pm 0.008$ & $0.034 \pm 0.004$ & $<0.01$ \\
$\mathrm{~F} \mathrm{~T}_{4}$ iodine $\mathrm{m} \mu \mathrm{g} / \mathrm{dl}$ & $2.37 \pm 0.75$ & $2.27 \pm 0.57$ & N.S \\
$\mathrm{F}_{\mathrm{T}}$ concent. $\mathrm{m} \mu \mathrm{g} / \mathrm{dl}$ & $3.5 \pm 1.0$ & $3.5 \pm 1.0$ & N.S \\
$\mathrm{PBI} \mu \mathrm{g} / \mathrm{dl}$ & $5.8 \pm 1.6$ & $6.7 \pm 1.4$ & N.S \\
\hline
\end{tabular}


は老若に全く差をみなかつた。, 又, free $\mathrm{T}_{4} \%$ は, TBG capccity と相関を示さず，TBPA と逆相関 が成立した。 即ち, 老人では TBPA の減少が free $\mathrm{T}_{4}$ の相対的濃度の増加と深い関係があると考光ら れ, 前述の如く, 老人の TBPA の有意の減少は, この free $\mathrm{T}_{4} \%$ の有意の増加を説明するに足ると 考元られた。

\section{Thyroxine の末梢代謝に関する老人の特徵}

Table 8 は健常人97例の体表面積当りの消費熱量
Table 8. Galorie expenditure in different age

\begin{tabular}{c|r|r|r|c}
\hline Age & Cases & Male & Cases & Female \\
\hline \hline 20 29 & 3 & $41.0 \pm 6.24$ & 1 & 38.0 \\
30 39 & 13 & $40.3 \pm 4.53$ & 3 & $39.3 \pm 1.53$ \\
$40 \sim 49$ & 16 & $38.0 \pm 4.55$ & 7 & $34.8 \pm 4.60$ \\
$50 \sim 59$ & 20 & $37.2 \pm 4.67$ & 10 & $34.3 \pm 6.57$ \\
$60 \sim 69$ & 14 & $37.3 \pm 5.13$ & 7 & $34.1 \pm 6.17$ \\
$70 \sim 79$ & 2 & $33.0 \pm 1.41$ & 1 & 35.0 \\
\hline
\end{tabular}
を示し,加令にともなつて減少するととから,老人で は未梢における甲状腺ホルモンの消費の低下が推定される. Shock ${ }^{6)}$ はアンチピリン法によつて体水分量を 測定し, 老人における基礎代謝率の低下は, 脂肪組織や, 間質の割合が増加しているためで, 個々の実質細胞の 代謝は老若で不変であろうと結論している，本邦においても篠原帛の業積があり，又，田内 ${ }^{9)}$ は肝の組織学 的な検索から老年期にみられる臟器組織重量の減少は, 実質細胞数の減少による面が多く, 個々の細胞はむし ろ活発な状態にあると推論している，從つててれらの所見から老人の甲状腺が単にその機能をおとしている というよりは，むしろ甲状腺ホルモンの働く場所が量的に減少していると考えられる．従つて未梢における Thyroxine の turnover をみることはきわめて興味あるととと考元られる. 予め過塩素酸カリ $600 \mathrm{mg}$ を毎 日分 4 亿して経口投与し, 甲状腺への無機ヨードのとりとみをブロックした状態で ${ }^{131}$ Thyroxine を約 100 $\mu \mathrm{c}$ 静注し, 経日的にその消費を PBI ${ }^{131}$ のカウント数でみたものである. Fig. 4, Fig. 5 はその結果を示す. 平均年令 77 才の老人 9 例の半減期の平均值は 6.8 日で, 若年者 6 例のそれは 5.5 日と短く, turn over rate の計算では, 老人の方が少い結果がえられた. 即ち老人における未梢組織の thyroxine の消費は若年者に 比して娍少しており，てのためにも血中のホルモン值は低くて足りていると考えられる.

Fig. 4. Disappearance curves of PBI
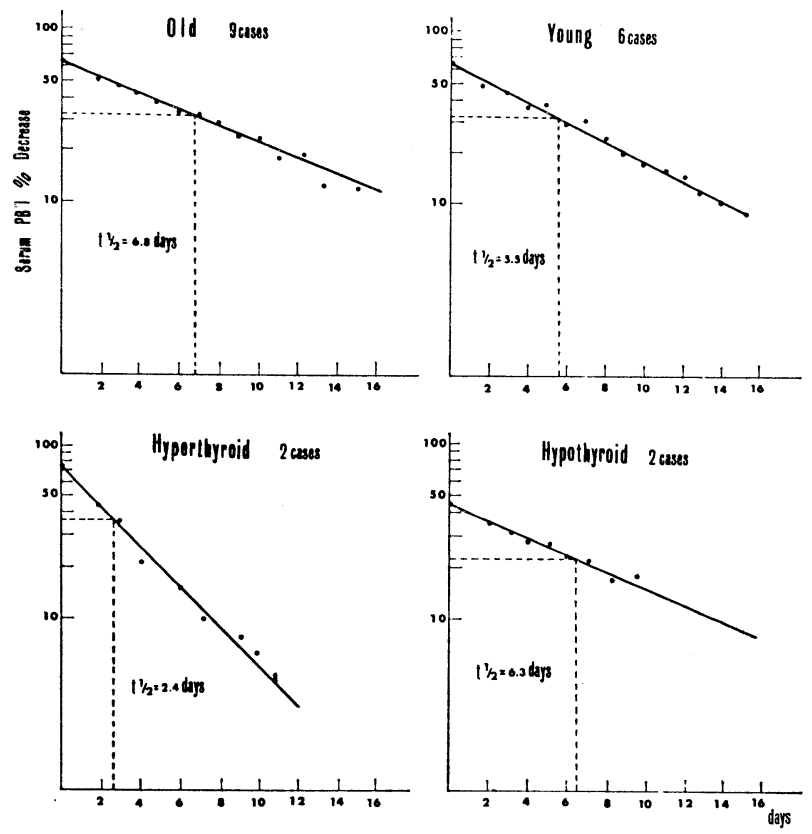

第 45 巻 第 7 号 
Fig. 5. Turnover data
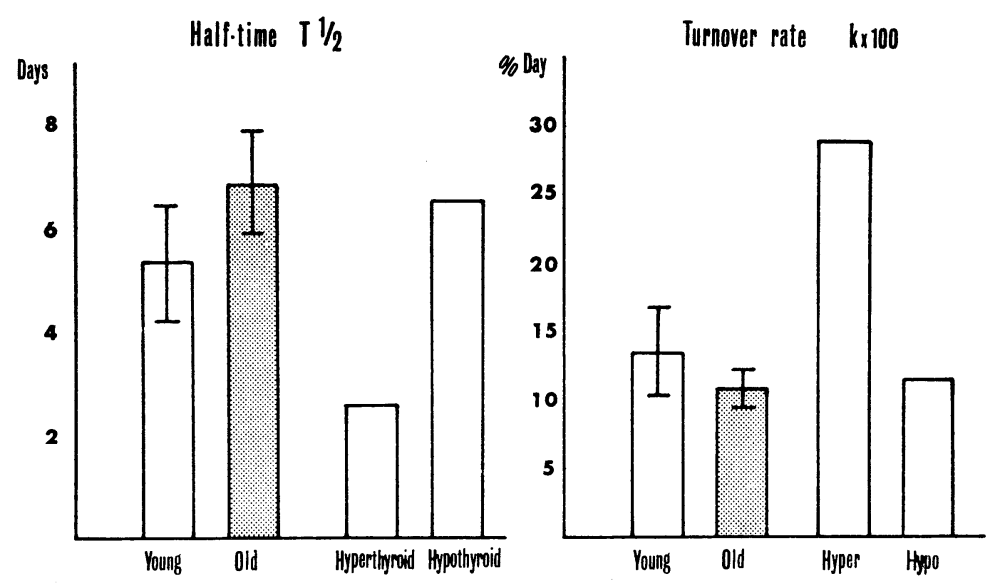

Table 9. Ghanges of PBI after TSH administration

\begin{tabular}{l|c|c|c|c}
\hline \multirow{2}{*}{} & \multicolumn{2}{|c|}{ Old 15 cases } & \multicolumn{2}{|c}{ Young 5 cases } \\
\cline { 2 - 5 } & PBI & \% Increase & PBI & \% Increase \\
\hline \hline Before & $5.3 \pm 1.1$ & 100.0 & $5.3 \pm 0.5$ & 100.0 \\
$24 \mathrm{hrs}$ & $6.5 \pm 1.3$ & $124.8 \pm 22.9$ & $6.1 \pm 0.5$ & $115.7 \pm 13.4$ \\
$48 \mathrm{hrs}$ & $6.3 \pm 1.1$ & $121.4 \pm 18.1$ & $5.9 \pm 0.6$ & $110.7 \pm 17.8$ \\
\hline
\end{tabular}

Mean age 77yrs. Mean age 22yrs.

Table 10. Change of Triosorb after TSH administration

\begin{tabular}{l|c|c|c|c}
\hline \multirow{2}{*}{} & \multicolumn{2}{|c|}{ Old 35 cases } & \multicolumn{2}{c}{ Young 16 cases } \\
\cline { 2 - 5 } & Triosorb & \% Increase & Triosorb & $\%$ Increase \\
\hline \hline Before & $29.5 \pm 3.9$ & 100.0 & $31.4 \pm 2.1$ & 100.0 \\
$24 \mathrm{hrs}$ & $33.1 \pm 4.8$ & $112.0 \pm 7.6$ & $34.5 \pm 3.5$ & $109.6 \pm 7.6$ \\
$48 \mathrm{hrs}$ & $32.3 \pm 4.8$ & $109.3 \pm 7.9$ & $33.1 \pm 3.0$ & $106.3 \pm 6.3$ \\
\hline
\end{tabular}

Mean age $75 y r s . \quad$ Mean age 22yrs.

\section{TSH 負荷試験}

高令者に下垂体の tropic hormone を負荷した場合, 老化した target organ が果して反応するであろう かというととは，内分泌の老化が下垂体の先行によるものか，或は target organ の先行によるものかとい う問題の解決に一つの足がかりとなると考えられる．吾々は 6 年前から約 40 例 の平均令 77 オ高令者に TSH (Thytropar, Armour 社) を 5 USP 単回筋注しててれに対する反応を, 前, 24時間, 48時間後に採血し $\tau$, 夫々 PBI, Triosorb, TBG, endogenous TBG, TBPA, Free $\mathrm{T}_{4}$ Index などを測定し, 若年群と比較 してきた，予想に反して老人に TSH を負荷すると，Table 9, Table 10 の如く, PBI, Triosorb, Tetrasorb の何れを指標にとつても，かなりの高令者においても，よく反応するととが判明し，てのととは，前 述の老人の甲状腺の組織学的な検索からもうかがわれるとてろである. 又, ての場合の total TBG, TBPA， endogenous binding TBG, free $\mathrm{T}_{4}$ Index (clark 法) などについても同時に観察し, 教室の鴻山只が報 
Table 11. Free $\mathrm{T}_{4}$ after $\mathrm{TSH}$ administration in old and young aged young 6 cases, old 5 cases

\begin{tabular}{|c|c|c|c|c|}
\hline & & Before & $24 \mathrm{hrs}$. & $48 \mathrm{hrs}$. \\
\hline PBI & $\begin{array}{l}\text { old } \\
\text { Young }\end{array}$ & $\begin{array}{l}6.1 \pm 1.1 \\
6.7 \pm 0.4\end{array}$ & $\begin{array}{l}8.2 \pm 1.2 \\
7.9 \pm 2.2\end{array}$ & $\begin{array}{l}7.7 \pm 0.7 \\
7.3 \pm 2.0\end{array}$ \\
\hline $\mathrm{F}-\mathrm{T}_{4} \%$ & $\begin{array}{l}\text { Old } \\
\text { Young }\end{array}$ & $\begin{array}{l}0.038 \pm 0.007 \\
0.035 \pm 0.007\end{array}$ & $\begin{array}{l}0.040 \pm 0.003 \\
0.036 \pm 0.007\end{array}$ & $\begin{array}{l}0.038 \pm 0.002 \\
0.036 \pm 0.005\end{array}$ \\
\hline $\mathrm{F}-\mathrm{T}_{4}$ Iodine & $\begin{array}{l}\text { Old } \\
\text { Young }\end{array}$ & $\begin{array}{l}2.40 \pm 0.80 \\
2.31 \pm 0.30\end{array}$ & $\begin{array}{l}3.32 \pm 0.51 \\
2.82 \pm 0.93\end{array}$ & $\begin{array}{l}2.88 \pm 0.08 \\
2.59 \pm 0.68\end{array}$ \\
\hline $\mathrm{F}-\mathrm{T}_{4}$ Concent & $\begin{array}{l}\text { Old } \\
\text { Young }\end{array}$ & $\begin{array}{l}3.7 \pm 1.2 \\
3.3 \pm 0.3\end{array}$ & $\begin{array}{l}5.0 \pm 0.8 \\
4.3 \pm 1.4\end{array}$ & $\begin{array}{l}4.4 \pm 0.4 \\
4.0 \pm 1.0\end{array}$ \\
\hline
\end{tabular}

Fig. 6. $\%$ Increase of free- $\mathrm{T}_{4}$ after $\mathrm{TSH}$ administration in old and young aged

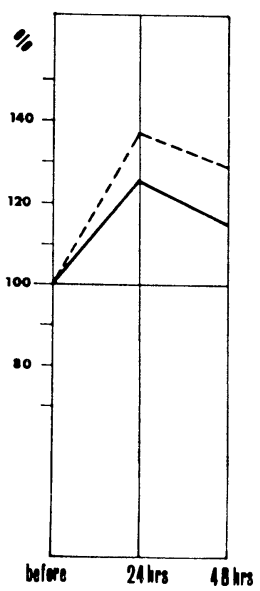

PBI

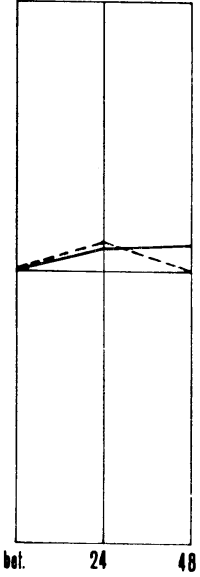

$\mathrm{F} \cdot \mathrm{T} \%$

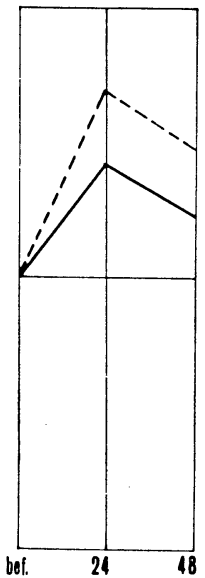

F. Th lodine

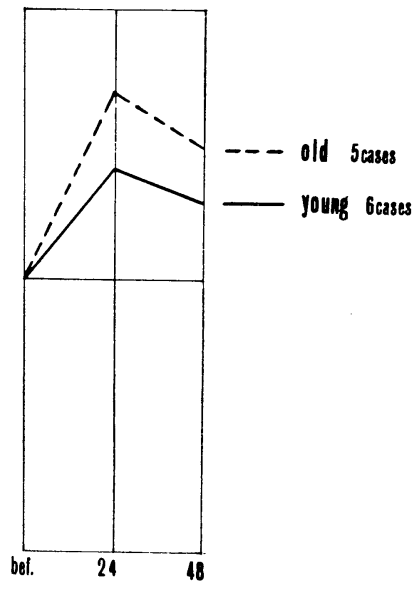

F. T/ Goncent.

告しているが, TSH 負荷によつても, total TBG capacity はわずかに3.1\%の増加をみるのみで, 前值と は間に有意差はみられなかつた，

次に TSH 負荷時の free $\mathrm{T}_{4}$ との相関をみると $\mathrm{Table} 11$ の如く, free $\mathrm{T}_{4}$ iodine, free $\mathrm{T}_{4}$ concentration 共に増加するが, free $\mathrm{T}_{4} \%$ は, 殆んど増加せず, Fig. 6 は, 前值を $100 \%$ とした時の増減率を図示したも のである. 更に free $\mathrm{T}_{4} \%$ と, TBG, endogenous TBG, TBPA などを同一人につき, 同時に測定しえた 老若 3 例づつの変化を示すと, Table 12 は, その実測值を, Fig. 7 は, 前值を $100 \%$ した場合の増減率を 図示したものである. 即ち, TSH の負荷により endogenous binding TBG は, 当然のととながら増加す るが, free $\mathrm{T}_{4} \%$ は老人において増加せず, 老人の大きな TBG が TSH によつて動員されたサイロキシ ンを捕束し，遊離型えの移行をおくらせる Buffer 作用を示したものと考えた．更にての点を確めるために， 老若各々 3 例づつの健常人に 7 日間乾燥甲状腺未 $0.04 \mathrm{~g}$ を 7 日間投与し，最後の投薬後 3 時間後に採血して， その前後の free $\mathrm{T}_{4} \%$ の動きをみたのが, Table 13 表である。老人例の值は $1.8 \%$ のみで, 若年者群の 16.6\%の増加に比して少く, 吾々の推論をうらづけたものと考えている.

\section{5. 動脈硬化症と甲状腺}


Table 12. TBP and Free $\mathrm{T}_{4}$ after $\mathrm{TSH}$ administration in old and young aged, each 3 cases

\begin{tabular}{l|l|c|c|c}
\hline \hline & & Before & $24 \mathrm{hrs.}$ & $48 \mathrm{hrs.}$ \\
\hline \multirow{2}{*}{ TBG } & Old & $28.6 \pm 2.4$ & $31.9 \pm 2.8$ & $30.9 \pm 2.0$ \\
& Young & $21.2 \pm 0.3$ & $21.3 \pm 2.7$ & $22.4 \pm 3.8$ \\
\hline \multirow{2}{*}{ end. TBG } & Old & $8.0 \pm 0.6$ & $9.9 \pm 2.1$ & $8.5 \pm 0.8$ \\
& Young & $6.1 \pm 0.5$ & $7.1 \pm 0.9$ & $6.9 \pm 0.5$ \\
\hline \multirow{2}{*}{ TBPA } & Old & $123.6 \pm 4.9$ & $125.3 \pm 1.6$ & $126.0 \pm 3.1$ \\
& Young & $121.9 \pm 2.8$ & $120.9 \pm 3.0$ & $116.0 \pm 9.7$ \\
\hline \multirow{2}{*}{ PBI } & Old & $6.9 \pm 0.1$ & $8.7 \pm 0.4$ & $7.5 \pm 0.8$ \\
& Young & $6.8 \pm 0.4$ & $9.1 \pm 1.7$ & $8.5 \pm 1.6$ \\
\hline \multirow{2}{*}{ F-T ${ }_{4} \%$} & Old & $0.042 \pm 0.004$ & $0.040 \pm 0.003$ & $0.039 \pm 0.004$ \\
& Young & $0.030 \pm 0.002$ & $0.032 \pm 0.004$ & $0.032 \pm 0.003$ \\
\hline \multirow{2}{*}{ F-T ${ }_{4}$ iodine } & Old & $2.90 \pm 0.41$ & $3.39 \pm 0.13$ & $2.91 \pm 0.18$ \\
& YounF & $2.11 \pm 0.14$ & $2.95 \pm 1.05$ & $2.82 \pm 0.77$ \\
\hline \multirow{2}{*}{ F-T ${ }_{4}$ concent. } & Old & $4.4 \pm 0.6$ & $5.2 \pm 0.2$ & $4.5 \pm 0.3$ \\
& Young & $3.2 \pm 0.2$ & $4.5 \pm 1.6$ & $4.3 \pm 1.2$ \\
\hline
\end{tabular}

Fig. 7. $\%$ Increase of $\mathrm{TBP}$ and free $\mathrm{T}_{4}$ after $\mathrm{TSH}$ administration in old and young aged
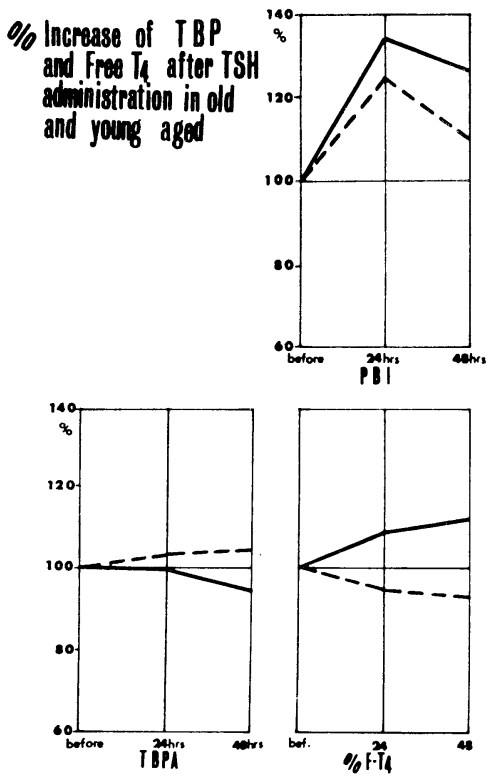
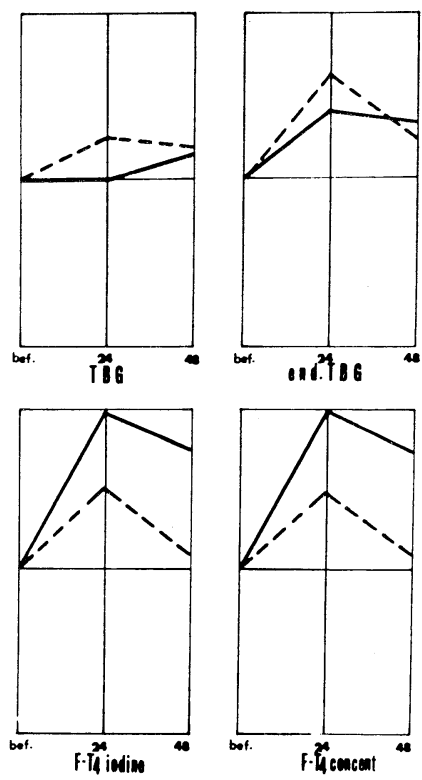
Table 13. $\% \mathrm{~F}_{-} \mathrm{T}_{4}$ after thyroid-powder administration for 7 days in old and young aged (each 3 cases)

\begin{tabular}{c|c|c|c|c}
\hline & \multicolumn{2}{|c|}{ Old } & \multicolumn{2}{c}{ Young } \\
\hline & $\%{\mathrm{~F}-\mathrm{T}_{4}}$ & $\%$ Increase & $\% \mathrm{~F}_{-} \mathrm{T}_{4}$ & $\%$ Increase \\
\hline \hline Before & $0.041 \pm 0.004$ & 100 & $0.031 \pm 0.005$ & 100 \\
After & $0.042 \pm 0.006$ & $101.8 \pm 8.9$ & $0.036 \pm 0.004$ & $116.6 \pm 8.3$ \\
\hline
\end{tabular}

Table 14. Effect of Mercapto-imidazole (120mg for 7 days) on PBI and TSH in normal youn'g subjects and patients with senile dementia

\begin{tabular}{l|c|c}
\hline \hline & PBI \% change & TSH \% change \\
\hline normal young subjects & $80.6 \pm 16.26(10)$ & $186.1 \pm 131.53 \quad(9)$ \\
patients with senile dementia & $80.4 \pm 22.96(11)$ & $80.9 \pm 42.17 \quad(8)$ \\
\hline
\end{tabular}

加令にともなう Pathological aging そ最も関係 の深い動脈硬化病と甲状腺との関係はきわめて重要 な課題である，さきに小倉は，第11回日本内分泌西 日本地方会において, 動脈硬化症には, 潜在性の甲 状腺機能低下症の存在が推測されると報告したが, 脳動脈硬化症に基因すると考えられる老人性痴朵症 に抗甲状腺剤を大量投与して，その TSH の分泌を McKenzie 法で測定し, 対照の正常人群に比して後 者では TSH の分泌が障害されていることを証明し た. (Table 14), 更に, 3 匹の両内頸動脈禁犬 (但し, 予め $\mathrm{Xe}^{133}$ 注入法で脳循環血流量が平均して 18\%おちているととを確認しておいたもの) に片側 甲状腺を剔出し，血中の TSH 量を同様に測定し，片甲状腺剔出術のみをおこなつた対照犬に比して，両 内頸動脈結紮群では片甲状腺剔出術をわてなつても TSH の上昇度が図の如くわるいてとをみとめた (Fig. 8). 一般に老人では若年者に比して Feed Back 機構の障害があるといわれているが，その原因の一 つとして動脈硬化による脳循環血流量の減少が重要な因子として考えられるととを示した。

\section{B. 加令現象に及ぼす甲状腺の意義}

\section{1. 老化度について}

甲状腺機能の低下が，所謂加令現象にどの程度の影響を有するかを検討するため，甲状腺機能低下症33例 をえらびその老化度を測定した，老化の基準となる老化度の判定については，第 8 回日本老年医学会総会に おいて報告したが, 肺活量, 皮膚の退縮率, 聴力, 骨のレントゲン線透過度等, 諸々あげられるか, Table 15 の如く生理的年令評価点はきわめてよく年令と一致して上昇するのでてれを採用した. Fig. 9 は, 正常人群 と甲状腺機能低下症群との加令による生理的年令評価点の相関を示したもので大体後者で約10才ぐらいの点 数の増加がみられた.

このような相関は, 年令の因子をのぞいても成立し, 即ち, 同じ年令㬝についてみても，甲状腺ホルモン の低下している場合に, その生理的年令評価点の上昇がみられた. 勿論, 生理的年令評価点の上昇が, ただ 
Table 15. Grade of aging in euthyroid and hypothyroid sudjects estimated by point system, increasing point shows advanced age

\begin{tabular}{c|r|r|r|r|r|r}
\hline \multicolumn{5}{|c|}{ Nor mal } & \multicolumn{2}{|c}{ Hypothyroid } \\
\hline Age & Cases & Male & Cases & Female & Cases & \\
\hline \hline$<24$ & 8 & $6.3 \pm 5.8$ & 6 & $4.5 \pm 3.4$ & & \\
$25 \sim 29$ & 11 & $6.8 \pm 7.1$ & 4 & $6.8 \pm 5.9$ & 2 & $6.3,20.0$ \\
$30 \sim 34$ & 33 & $9.5 \pm 5.7$ & 11 & $9.8 \pm 4.5$ & & \\
$35 \sim 39$ & 71 & $13.9 \pm 6.7$ & 24 & $12.6 \pm 6.7$ & 4 & $19.6 \pm 7.8$ \\
$40 \sim 44$ & 88 & $13.7 \pm 8.1$ & 25 & $13.3 \pm 9.2$ & & \\
$45 \sim 49$ & 87 & $19.5 \pm 10.6$ & 26 & $19.8 \pm 9.7$ & 7 & $32.0 \pm 11.0$ \\
$50 \sim 54$ & 109 & $23.1 \pm 10.1$ & 35 & $25.6 \pm 10.7$ & & \\
$55 \sim 59$ & 99 & $27.9 \pm 10.2$ & 25 & $28.3 \pm 13.7$ & 11 & $34.6 \pm 6.0$ \\
$60 \sim 64$ & 104 & $31.5 \pm 10.7$ & 21 & $30.9 \pm 11.8$ & & \\
$65 \sim 69$ & 56 & $34.3 \pm 10.5$ & 12 & $38.5 \pm 10.2$ & 9 & $43.5 \pm 8.9$ \\
$70 \sim 74$ & 16 & $39.7 \pm 10.7$ & 4 & $405 . \pm 6.6$ & & \\
$75 \sim 79$ & 5 & $38.8 \pm 13.5$ & 2 & $20.0,26.7$ & & \\
\hline & 687 & & 195 & & 33 & \\
\hline
\end{tabular}

Fig. 9. Graphic comparison of aging sign of euthyroid and hypothyroid subjects, hypothyroidism is accompanied by advanced aging sign

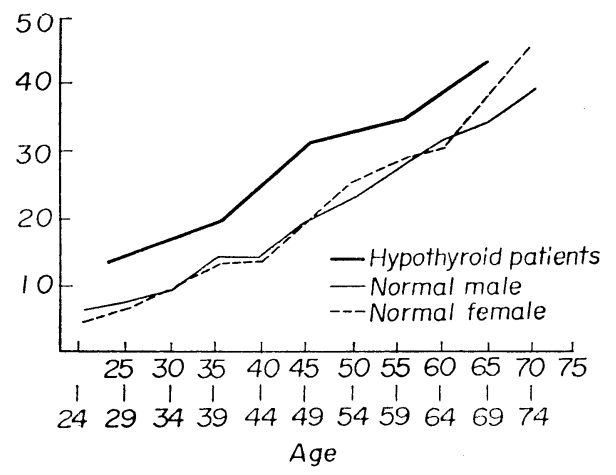

ちに老化の促進とはいえないが，Hypothyroidism の患者では，Pathological aging の促進が推定さ れる。

\section{2. 甲状脂機能低下症の予後調査}

前述の如く, 本症では, 所謂 Pathological aging の促進のために，長寿を全うするものは少いであろ うとの想定のもとで, 本症の予後調査をおてなつ た。対照は神戸市隈病院で，昭和10年から同32年ま で甲状腺剔出術をうけた4359例中, 顕微鏡学的に橋 本氏病と診断されたもので, 何れも術後, 甲状腺機 能低下症状ありと，カルテに記載のあつた208例に， アンケートを出して回答がえられた83例について, 日本生命学術調查課の協力をえて, その予定死亡数 を算出した. 予定死亡数は $\sum_{n} \sum_{x=i}^{s} q x$ で算出される.

ここに $i$ は観察開始時の年令, $\mathrm{S}$ は調査時の年令 (死亡の場合は死亡年令) $q x$ は各才毎の死亡率, $\mathrm{n}$ は症例 数を示す．又，各才毎に累加する死亡率は，なるべくその年に近い時期の生命表によつた．その結果による と, 83例の予定死亡数は， 23,78 人となり，実死亡数 14 例の場合の危険率 $5 \%$ の最低予定死亡数を Poason の数表からもとめると 21,65 人となり，83例の手術例の予定死亡数より有意に少く，長命であるという予想 外の結果がえられた。一般妇状腺ホルモンは生体にとつて catabolic に, あるいわ calorigenic に作用 するととは周知のてとであるが，乙のホルモンの低下は，前述の加令現象を促進するようであるが，細ばそ と生ながらえ，長寿を全うするためにはかえつて少い方が有利であるという推論がなされる。

\section{結語}

以上加令と甲状腺という課題に対して，結果論的と，原因論的な観点の雨面から考察をおとなつた。 
日本医学会総会にわいてのべた如く, 吾々の観察でも, 甲状腺の老化が先行して所謂老化の支配的な原因 となりうるとは考えがたく, 一般臟器の老化と平行して, 甲状腺も徐々にその機能をおとしてゆくようであ る.しかし TSH で刺激をおてなえば，かなりの高令になつてもてれに対処しうるだけの能力を有してい るてとが判明した。無事安静の時には未梢の細胞代謝の低下に応じて, その機能をおとし, 又, 老人におけ る TBG capacity の有意の増加は急激な甲状腺ホルモン増加に対して一つの Buffer の作用を演じている とも考えられ，ての説をうらづける結果もえた。しかし甲状腺と間脳下垂体との Feed-Back 機構は明かに 若年群に比して障害されており，てれには脳動脈硬化にともなう脳循環血流量の減少がその一因となつてい るととを実験犬を用いて観察した。

又, 甲状腺機能低下症にわける先述の老化指数の上昇は, Pathological aging を促進せしめると考元ら れ, 外見上の老化の促進は, 臨床的にもしばしば経験されるとてろである. しかし, 加令にともなう甲状腺 機能の低下は，長寿という目的には，必ずしも不利なものではなく，てのような方面にも生物の合目的な適 応乃至 Homeostasis が考えられた。

\section{文献}

1）小倉 一, 新光 毅: 第11回日本内分泌学会西日本地方会シンポジゥムにて発表。 2 2) 小倉一： 第17回日本医学会総会学術講演集, $3: 631,(1967) . \quad 3)$ 辻 昇二・他：高令医学, $7: 29$, (1969). 4) 入江一彦: 東北医誌, $55: 321$, (1957).

E.B. : J. Clin. Invest., $33: 1031$, (1954) 5) STERLING, K., LASHOF, J.C., and MON, gerontology." The National Vitamin Foundation, New York, (1954), p. 20

6) SHOCK, N.W. : "Symposium on problems of 令医学, $6: 399,(1969)$.

7) 鴻山千秋 : 高 (1964).

8) 篠原恒樹 : 第6回日本老年医学会総会シンポジウム講演, 東京,

\section{追加発言}

小児期及び青春期の甲状腺機能

千葉大学小児科

中島 博 德

新生児の甲状腺機能は生後数日迄は, Triosorb 值, $\mathrm{T}_{4}-\mathrm{I}$ 值は異常に高く, 文献的に見られる thyroidal uptake と合せて, 生理的に hyperactive といえる.

新生児期以後, 乳呪, 幼児, 学童, 青春期, 成人の Triosorb 值, $T_{4}-I$ 值, free $T_{4}$ index, thyroidal uptake (24時間值), PBI 值等は何れも有意の差がない, 従つて之等の検査からは小児期甲状腺機能の特殊 性を知ることができなかつた。

そてで, 33人についてョード代謝を検查した所, 血漿無機ヨード值は, 小児期<青春期<成人であり, 腎 ヨードクリアランスは, 小児期 $>$ 青春期 $>$ 成人であり, 甲状腺ヨードクリアランスは同じく, 小児期 $>$ 青春 期入一成人の関係を示した。 即ちョード代謝は幼若程活発であり, 乙れらの変化は年令的に略直線的に推移す

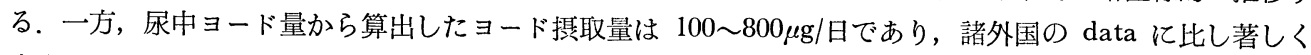
高く, ヨード久之の起る可能性は少ない.

次に，57人について $\mathrm{T}_{4}$ 代謝を検查した所，血中半減期は，小児 $<$ 青春期 $<$ 成人, 従つて turnover rate は, 小児 $>$ 青春期 $>$ 成人となり， $\mathrm{T}_{4}$ 未梢崩壊量は, 小児 $>$ 青春期 $>$ 成人となつた。 従つて $\mathrm{T}_{4}$ 代謝も幼若 程活発で，年令的に略直線的に変化する，以上から小児の甲状腺機能は成人に比し hyperactive であると いえる。 
甲状腺重量の年令的推移を文献的にみると, 小児期は絶対重量は勿論, 体重当りでも成人より小さく，乙 れでいて機能は hyperactive であるてとは興味深い。甲状腺重量は青春期に急激に増大する。乙れは女性 に於て著明である。

視触診による甲状腺の大きさを，千葉市の小，中，高校生7000人について調い゙ると，明らかに青春期の女 子に於て, 甲状腺腫大がみられ，2.5度以上のものは $2 \%$ に相当する。

青春期女子の生理的甲状腺腫大の成因は, 従来からなされている青春期の成長促進に伴うホルモン需要量 の増大とする考えは, 小児期から成人期へ直線的に減少する上述の $\mathrm{T}_{4}$ 代謝成績からも否定され, 又筒ヨード クリアランスの高まりによるヨードの相対的欠乏とする考旮も小児期は青春期より高いという上述の成績か ら否定される．更に女子に特異的であるてとより．estrogen の役割に注目せざるを得ない。

estrogen の甲状腺に及ぼす効果は古くより論じられているが未だに定説がない. 我々もラットに estra diol benzoate $50 \mu \mathrm{g} /$ 日, progesterone $3.5 \mathrm{mg} /$ 日, methylthiouracil $1 \mathrm{mg} /$ day を単独又は併用で 3 週間観 察したが, estradiol の甲状腺重量增加作用を認め, 従来の一部の報告と一致した.

次に， estrogen の $\mathrm{T}_{4}$ 結合蛋白に及ぼす影響をみた。 201例でみた $\mathrm{T}_{4}$ distribution \% (affinity) と maximal binding capacity は, TBG は小児期より成人に向つて次第に減少し, TBPA は逆に次第に増 加する，注目すべきは，小児期では見られなかつた性差が青春期より認められ，TBG は女子が男子よりも 優位で， TBPA はその逆であつた。 ての差は青春期以降に於ける内因性の estrogen と androgen の量的 関係によつて生じたものであると考えられる。

乙の結合蛋白の年令的, 性的変化が甲状腺に如何なる影響を与えらるか不明である. しかし 1 つの可能性 として, estrogen 分泌の周期性に注目したい. estrogen の周期的変化は, 当然 $\mathrm{T}_{4}$ 結合蛋白の周期的変化 につながり，てれが下垂体，甲状腺系を不安定に導く因子，ひいては青春期に多発する青春期性甲状腺嗹を 始めとした種々の甲状腺疾患の成因の 1 つになり得ると考えたい。

体甲状腺系を不安定に導く因子，ひいては青春期に多発する甲状腺腫を始めとした種々の甲状腺疾患の成 因の 1 つと考えたい.

質問：虎の門病院内分泌科 鎮目和夫 1) 加令により Tetrasorb で測定した $\mathrm{T}_{4}$ は低下するのに PBI は あまり低下していないという結果であるがその差異は何によるか,

2）老人では TBG は増加しているのにも拘らず Free $\mathrm{T}_{4}$ の\%が若年者より高いという結果が示された が何故に Free $\mathrm{T}_{4}$ が高いのか

3）甲状腺機能低下症の予後調查の結果本症患者は長命であるという結果を示されたが，その様な患者は 甲状腺ホルモンの投与を受けていたのか. 若し治尞されていた群とされていなかつた群とがあるのならその 間に寿命に差は認められたか. 